\title{
Non-secretory multiple myeloma presenting as pathological fractures: a diagnostic dilemma
}

\author{
Fracturas patológicas como forma de presentación de un mieloma \\ múltiple no secretor: un dilema diagnóstico
}

Emilio Guirao Arrabal ${ }^{1}$, María Francisca Parra Montoya ${ }^{2}$, Jesús González Oliveros ${ }^{3}$, María Montes Ruiz-Cabello ${ }^{1}$, Pedro Luis Carrillo Alascio ${ }^{1}$

${ }^{1}$ Internal Medicine Unit. Hospital La Inmaculada. Huércal-Overa, Almería, Spain

${ }^{2}$ Radiology Unit. Hospital La Inmaculada. Huércal-Overa, Almería, Spain

${ }^{3}$ Haematology Unit. Hospital La Inmaculada, Huércal-Overa, Almería, Spain

\begin{abstract}
We present the clinical case of a 60 year-old woman who was admitted to our hospital referring a precordial pleuromechanic pain and was diagnosed with multiple bone fractures. A bone marrow biopsy gave the diagnosis of multiple myeloma and no monoclonal peak was detected, neither light chains in blood nor urine. The final diagnosis was non-secretory multiple myeloma and secondary spontaneous fractures. Nonsecretory multiple myeloma represents only $3 \%$ of all multiple myelomas and has several characteristics that make it important to distinguish from other myelomas
\end{abstract}

\section{Resumen}

Presentamos el caso de una mujer de 60 años de edad que acudió a nuestro hospital por dolor precordial pleuromecánico y fue diagnosticada de fracturas óseas multiples. La biopsia de médula ósea dio el diagnóstico de mieloma multiple y no se detectó pico monoclonal, ni tampoco cadenas ligeras en sangre ni orina. El diagnóstico final fue de mieloma múltiple no secretor y fracturas espontáneas secundarias. El mieloma múltiple no secretor representa solo el $3 \%$ del total de mielomas múltiples y tiene características peculiares que hacen necesaria su distinction del resto de mielomas.
Keywords: multiple myeloma; non-secretory multiple myeloma; bone marrow biopsy.

\section{INTRODUCTION}

Pathological fractures represent a diagnostic challenge by including in their differential diagnosis several types of solid tumors, hematological neoplasms, endrocrinometabolic pathologies, and also primary benign and malignant bone tumors and even bone infectious processes. We present a case of a patient with multiple pathological fractures who was diagnosed by bone marrow biopsy.

\section{CLINICAL CASE}

A 60-year-old woman, smoker of 20 cigarettes/day, without any previous disease, and no familiar history of interest, was admitted to our hospital referring an intense, precordial, sudden onset pleuromechanic pain. The patient was hemodynamically stable, afebrile and breathing eupneic. At the abdominal palpation, she had epigastric pain, radiated from the sternum. The rest of examination was normal. She had a weight of $45 \mathrm{~kg}$ and a height of $1.55 \mathrm{~m}\left(\mathrm{BMI} 18.7 \mathrm{~kg} / \mathrm{m}^{2}\right)$.

Blood tests results: haemoglobin $10.9 \mathrm{~g} / \mathrm{dL}$; leukocytes, platelets and basic clotting study were normal; biochemical urea 60 $\mathrm{mmol} / \mathrm{dL}$, calcium $10.9 \mathrm{mg} / \mathrm{L}$, phosphorus $5 \mathrm{mg} / \mathrm{L}$, total proteins $6.3 \mathrm{~g} / \mathrm{L}$, and intact PTH $8.6 \mathrm{pg} / \mathrm{mL}$. Calcium and phosphorus in 24-hours-urine were both normal. The protein profile showed an elevation of alpha-1 and alpha-2 fractions, with reduced gamma fraction (IgG, $M$ and $A$ were low).

Chest X-ray and computed tomography (CT) showed generalized osteopenia, and a left clavicle and medial $3^{\text {rd }}$ left rib fractures. Abdominal-CT also showed a vertical right sacral wing fracture (image 1). Tecnecium-99 metastable scintigraphy confirmed a focus of tracer uptake in the left clavicle, but did not show any pathological deposition of activity attributable to a metastatic origin.

A bone-marrow biopsy (right iliac) was taken and sample sent for pathological study, which gave the final diagnosis of mul-

\section{$A C T \cup A L I D A D$ $M$ E D I C A www.actualidadmedica.es (0)2017.Actual.Med. Todoslos derechos reservados}

Emilio Guirao Arrabal.

Internal Medicine Unit. Hospital La Inmaculada. Avenida Ana Parra s/n. C.P. 04600. Huércal-Overa. Almería. España.

E-mail: emilio.guirao@gmail.com

Teléfono : +34950029151 


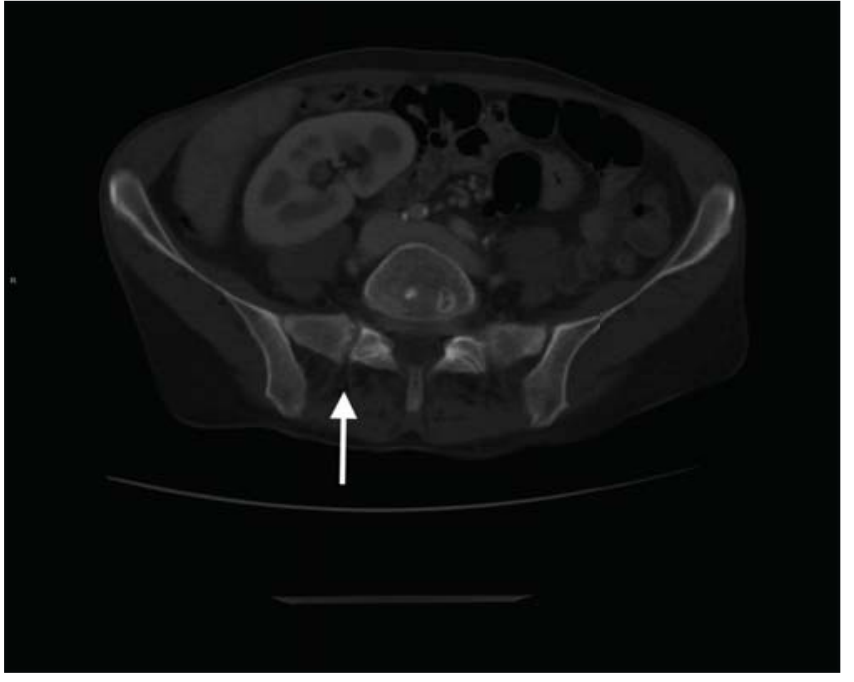

Image 1. Vertical right sacral wing fracture on computed tomography (arrow).

tiple myeloma (MM) (70\% neoplastic plasmatic cells: CD38 ++/+++, CD56 +, CD138+ and kappa IgG cytoplasmic; CD45 and CD117 negative). Kappa and lambda light chains and kappa/lambda index were normal in both blood and urine samples. No immunofixation was detected.

Final diagnosis: Non-secretory Multiple Myeloma (NSMM) associated with spontaneous fractures.

\section{DISCUSSION}

$\mathrm{MM}$ is a neoplastic disease whose origin is in the bone marrow infiltration by plasma cells that typically produce serum or urine proteins(1). Immunologically, non-secretory MM differentiates into those that produce immunoglobulins and others that do not. Therefore we must differentiate those tumors that have a deficit in protein production ("non-producing") from those who have a defect for protein secretion. Within the latter there is a subgroup that have the capacity to secrete small amounts of immunoglobulins (oligosecretory MM). Therefore we define as "true" NSMM as MM that does not produce immunoglobulins at all, given the current methods of immunofixation(2). This entity represents about $3 \%$ of all MM in some series(3). There is therefore confusion about the terminology and the current trend is to clearly establish the specific type of MM for every patient.

As for the clinical manifestations, the non-secretory MM tends to manifest with moderate to severe osteoporosis and bone fractures that can be multiple sometimes, as in our case (4). Anaemia is somewhat less frequent than in secretory MM and renal involvement is rare(2). In some series there seems to be a better prognosis of this subtype with respect to secretory $\mathrm{MM}(5)$.

The absence of a monoclonal gamma globulins' peak in proteinogram in NSMM can lead to difficulties in diagnosis. Clinicians may tend to perform some other explorations (endoscopies, PETscans, etc.) in a patient with several osteolytic lesions and no suspicion for MM, in order to seek for a primary tumor.

\section{CONCLUSION}

This case seems extremely interesting, because this condition must be in the differential diagnosis of secondary osteoporosis and multiple osteolytic processes, even when no monoclonal gammaglobulin's peak in protein electrophoresis is found. We in- sist in the need to perform a bone-marrow study in these patients, even when there is no positivity for light chains or immunofixation.

\section{Compliance with Ethical Standards:}

This article is a clinical case report. No patient information or patients identification images are reported, therefore no informed consent was required. All procedures performed in studies involving human participants were in accordance with the ethical standards of the institutional and/or national research committee and with the 1964 Helsinki declaration and its later amendments or comparable ethical standards. This case report has no funding.

Conflictos de interés: Todos los autores declaran no tener ningún conflicto de interés.

Fuentes de apoyo financiero: Ninguna.

\section{REFERENCES}

1. Palumbo A, Anderson K. Multiple Myeloma. N Engl J Med. 2011;364(11):1046-60.

2. Lonial S, Kaufman JL. Non-secretory myeloma: a clinician's guide. Oncology (Williston Park). 2013;27(9):924-928,930.

3. International Myeloma Working Group. Criteria for the classification of monoclonal gammopathies, multiple myeloma and related disorders. Br J Haematol. 2003;121:749-57.

4. Middela S, Kanse P. Nonsecretory multiple myeloma. Indian J Orthop. 2009 Oct;43(4):408-11.

5. Kyle RA, Gertz MA, Witzig TE, Lust JA, Lacy MQ, Dispenzieri A, et al. Review of 1027 patients with newly diagnosed multiple myeloma. Mayo Clin Proc. 2003;78(1):21-33. 